\title{
ANALISIS SALURAN DAN TINGKAT EFISIENSI PEMASARAN BERAS SEMI ORGANIK DI KECAMATAN RAMBUTAN KABUPATEN BANYUASIN
}

\author{
Muhammad Arbi, Thirtawati, Yulian Junaidi \\ Staf Pengajar Universitas Sriwijaya \\ Email:Arbiunsri@yahoo.com
}

\begin{abstract}
Semi-organic rice is an environtmentally and consumer friendly food product. However, one of the main problem associated with semi-organic rice and organic food in general is marketing, since it has spesific consumer and relatively higher price. Thus, studies focused on semi-organic marketing is of paramount important. The objectives of this study are, to identify marketing channel for semiorganic rice from farmer to consumer, analyze structure and conduct of semi-organic rice market, and analyze marketing efficiency of each marketing channel and the efficiency of each marketing organization in each channel. This study employed survey method based on questionnaire to guide the interview. The sample used in this study are 30 farmers randomly selected from a population of 95 semi-organic rice farmers located at Pangkalan village, on Gelebak sub-district, in the district of Banyuasin. Based on 30 sample farmers, the marketing channel for semi-organic rice was traced using snowball method and 2 collecting trader and 1 retail trader were identified. The result shows that there are two channels in the marketing of semi organic rice in the studied area, channel 1 (farmer-village level collecting trader-large collecting trader-retail trader-consumer) and channel 2 (farmer-village level collecting trader-konsumer). The second result shows that semi-organic rice market in the studied area tend to be monopolistic since there is no single actor control consumer, price, product, and transaction. The final result shows that each marketing channel of semi-organic rice is efficient.
\end{abstract}

Keywords: Semi-organic rice marketing, marketing efficiency, Rambutan sub-district

\section{PENDAHULUAN}

Pembangunan pertanian diarahkan untuk meningkatkan produksi pertanian guna memenuhi kebutuhan pangan dan kebutuhan industri dalam negeri, meningkatkan ekspor, meningkatkan pendapatan petani, memperluas kesempatan kerja dan mendorong pemerataan kesempatan berusaha. Salah satu komoditas strategis dalam mendukung pembangunan sektor ekonomi dan pemenuhan kebutuhan pangan nasional adalah padi. Kebutuhan beras sebagai komoditi pangan pokok akan terus meningkat. Menurut Pramono (2005), hal ini sejalan dengan pertambahan jumlah penduduk dan peningkatan konsumsi perkapita, sehingga optimalisasi produktivitas padi di lahan sawah menjadi salah satu upaya yang bertujuan untuk meningkatkan produksi gabah nasional dalam usaha peningkatan ketahanan pangan nasional.

Kesadaran akan pentingnya kesehatan dan kelestarian lingkungan mendorong masyarakat pertanian untuk kembali ke sistem pertanian organik karena produk yang dihasilkan bebas residu pestisida dan pupuk kimia. Selain ramah lingkungan, biaya untuk pertanian organik pun lebih rendah karena pupuk dan pestisida yang digunakan berasal dari alam di sekitar petani. Bila harus beli, harganya pun relatif murah (Andoko, 2006). Dampak negatif akan penggunaan pupuk, pestisida kimia, dan sarana produksi modern lainnya telah menumbuhkan kesadaran kepada petani akan pentingnya permasalahan lingkungan. Menurut Shirappa dan Razaq (2007) menyebutkan bahwa sebagian kecil dampak negatif tersebut membuat petani beralih dari pertanian konvensional ke pertanian organik.

Lahan yang dipakai beras semi organik adalah lahan yang belum organik atau belum dipakai tanam organik sampai 5 Tahun. Namun selain itu terutama dari penggunaan pupuknya sama saja dengan beras anorganik. Jika dibandingkan dengan beras yang anorganik (tidak organik) beras semi organik ini 
mempunyai segudang kelebihan karena proses pengolahannya yang berbeda. Beras semi organik penanamannya menggunakan kompos dan pupuk hijauan serta pemberantasan hama menggunakan pestisida alami yang dihasilkan dari daun-daunan dan buah-buahan yang difermentasikan secara alami. Proses organis itu sendiri akan dapat memperbaiki struktur dan kesuburan tanah, serta membangun ekosistem yang berkelanjutan. Selain itu, rasa dari beras semi organik ini pulen, wangi, dan tidak mudah basi. Daya tahan nasi dengan beras semi organik bisa mencapai 48 jam tanpa perlu menyimpan di lemari es (Kompasiana, 2013).

Selanjutnya untuk meningkatkan efisiensi, diperlukan studi mengenai sistem pemasaran dan permasalahan yang dihadapi oleh setiap pelaku pemasaran di dalam kegiatan pemasaran tersebut. Menurut Daniel (2002), semakin pendek rantai tataniaga dari suatu barang hasil pertanian maka akan mengakibatkan biaya tataniaga semakin rendah, margin tataniaga juga akan semakin rendah, dan harga yang harus dibayarkan konsumen juga semakin rendah serta harga yang diterima produsen akan semakin tinggi, sehingga saluran pemasaran tersebut akan semakin efisien.

Saluran pemasaran adalah serangkaian organisasi yang saling tergantung yang terlibat dalam proses untuk menjadikan produk atau jasa siap untuk digunakan atau dikonsumsi (Kotler, 2005). Ada beberapa saluran pemasaran beras semi organik yang ada di Desa Pangkalan Gelebak Kecamatan Rambutan Kabupaten Banyuasin. Melalui penelitian ini, akan terlihat bagaimana proporsi distribusi keuntungan masing-masing lembaga pada setiap saluran pemasaran, proses pembentukan harga, serta alternatif-alternatif saluran yang dapat dimaksimalkan untuk lebih lanjut meningkatkan pendapatan petani padi semi organik. Setiap saluran pemasaran memiliki tingkat efisiensi yang berbeda berdasarkan rantai pemasarannya. Berdasarkan uraian di atas maka peneliti tertarik untuk menganalisis saluran pemasaran beras dan tingkat efisiensi pemasaran beras semi organik di Desa Pangkalan Gelebak Kecamatan Rambutan Kabupaten Banyuasin.

Berdasarkan latar belakang penelitian tersebut di atas, maka tujuan dari penelitian ini adalah:

1. Mendeskripsikan saluran pemasaran beras semi organik dari tingkat petani hingga ke konsumen akhir di Desa Pangkalan Gelebak
Kecamatan Rambutan Kabupaten Banyuasin 2. Mengetahui struktur pasar dan perilaku pemasaran beras semi organik yang terjadi di Desa Pangkalan Gelebak Kecamatan Rambutan Kabupaten Banyuasin.

3. Menganalisis besar tingkat efisiensi pemasaran dari setiap saluran pemasaran dan tingkat efisiensi pemasaran dari masingmasing lembaga pemasaran pada setiap saluran pemasaran beras semi organik di Desa Pangkalan Gelebak Kecamatan Rambutan Kabupaten Banyuasin.

Hasil penelitian ini diharapkan berguna sebagai bahan pertimbangan bagi pemerintah setempat untuk menentukan kebijakan-kebijakan yang berkaitan dengan program peningkatan produksi beras berbasis ramah lingkungan menuju pertanian berkelanjutan.

\section{METODE PENELITIAN}

Penelitian didesain dengan metode surve dan dipilih Desa Pangkalan Gelebak dimana terdapat sebagian petani yang telah menerapkan sistem pertanian padi semi organik di Kecamatan Rambutan Kabupaten Banyuasin. Metode pengambilan sampel responden dilakukan dengan menggunakan rumus Slovin dengan tingkat kesalahan $15 \%$ pada populasi sebanyak 95 petani dan ditetapkan sebanyak 30 responden. Sementara untuk sampel pedagang dan konsumen digunakan metode snowball. Untuk mendapatkan data primer maupun sekunder, dilakukan wawancara dengan berpedoman pada kuisioner yang telah disusun serta pengamatan langsung terhadap aktivitas petani semi organik di lokasi penelitian.

Pendekatan yang digunakan untuk menngetahui saluran pemsaran yang terbentuk adalah dengan pendekatan deskriptif langsung yaitu dengan mengikuti aliran produksi padi semi organik dari petani produksen sampai ke konsumen akhir. Setelah diperoleh data primer, maka dapat diketahui bagaimana efisiensi pemasaran beras semi organik dan besarnya efisiensi masing-masing saluran pemasaran di Kecamatan Rambutan Kabupaten Banyuasin. Untuk mengetahui efisiensi diunakan rumus:

$$
\mathrm{MP}=\mathrm{Pr}-\mathrm{Pf}
$$

Di mana:

MP : margin pemasaran

Pr : harga di tingkat konsumen

Pf : harga di tingkat produsen

Share yang diterima petani: 


\begin{tabular}{|c|c|}
\hline \multicolumn{2}{|r|}{$\operatorname{Shp}=(\mathrm{pf} / \mathrm{pr}) \times 100 \%$} \\
\hline Shp & : share petani \\
\hline Pf & : harga di tingkat petani \\
\hline $\operatorname{Pr}$ & : harga di tingkat konsumen \\
\hline & $\begin{array}{l}\text { e keutungan lembaga pemasaran ke-i } \\
\text { Ski }=(\mathrm{Ki} /(\mathrm{pr}-\mathrm{pf})) \times 100 \%\end{array}$ \\
\hline $\mathrm{Ki}$ & $\begin{array}{l}\text { : keuntungan lembaga pemasaran } \\
\mathrm{Ki}=\mathrm{Pji}-\mathrm{Pbi}-\mathrm{Bij}\end{array}$ \\
\hline Pji & : Harga jual lembaga ke-i \\
\hline $\mathrm{Pbi}$ & : harga beli lembaga ke-i \\
\hline $\mathrm{Bij}$ & $\begin{array}{l}\text { : Biaya yang dikeluarkan lembaga ke-I } \\
\text { dari berbagai jenis biaya }\end{array}$ \\
\hline
\end{tabular}

\section{HASIL DAN PEMBAHASAN}

\section{Identitas Petani Sampel}

\section{a) Umur}

Usia Kerja adalah suatu tingkat umur seseorang yang diharapkan sudah dapat bekerja dan menghasilkan pendapatannya sendiri. Umur merupakan salah satu faktor yang menentukan kegiatan petani dalam mengelola usahataninya. Pada umumnya semakin tinggi umur maka kemampuan kerja akan semakin meningkat sampai pada batas tertentu. Umur petani contoh di Desa Pangkalan Gelebak bervariasi antara 30 sampai 60 tahun. Dengan rata-rata umur petani contoh di Desa Pangkalan Gelebak adalah 47,50 tahun, artinya umur petani contoh di Desa Sumber Suko tergolong usia produktif. Pada Tabel 4.5 dapat dilihat rincian tingkat umur petani contoh di Desa Pangkalan Gelebak Kecamatan Rambutan Kabupaten Banyuasin.

Berdasarkan Tabel 1, diketahui bahwa kelompok umur terbanyak untuk petani contoh yaitu kelompok umur 40-49 yaitu sebanyak 13 orang. Sedangkan kelompok umur yang paling sedikit adalah kelompok umur 60-69 yaitu sebanyak 2 orang. Berdasarkan tabel klasifikasi umur ini menunjukkan bahwa petani berusia produktif lebih banyak daripada petani berusia tidak produktif, yaitu dimulai dari rentan 30 tahun sampai 60 tahun masih produktif, sedangkan di atas 60 tahun tidak produktif lagi. Berdasarkan hasil lapangan, Petani dengan usia yang lebih dari 60 tahun, biasanya menyerahkan pekerjaan petaninya kepada anak cucu mereka sehingga tidak jarang diperoleh ketika wawancara bapak dan anak laki-laki memiliki profesi yang sama sebagai petani padi juga

\section{b). Pendidikan}

Tingkat pendidikan juga mempunyai pengaruh bagi petani dalam menjalankan usahataninya. Pendidikan yang tinggi dapat membantu petani dalam mengambil keputusan apabila petani dihadapkan oleh beberapa masalah yang berkaitan dengan kegiatan usahatani yang dilakukannya, serta tanggap terhadap perubahan yang terjadi di lingkungannya ataupun dalam mengadopsi suatu teknologi baru dibandingkan dengan petani dengan tingkat pendidikan yang rendah. Sedangkan apabila petani memiliki tingkat pendidikan yang tinggi dan cukup baik, dapat menyebabkan petani tersebut mampu untuk menyesuaikan pekerjaannya dengan hasil yang akan diperoleh nantinya. Petani contoh memiliki berbagai latar belakang pendidikan yang beragam mulai dari SD, SMP, SMA, sampai Perguruan Tinggi. Tabel 2 akan menunjukkan rincian tingkat pendidikan petani yang melakukan usahatani padi semi organik di Desa Pangkalan Gelebak Kecamatan Rambutan Kabupaten Banyuasin.

Tabel 2. Karakterisitk responden berdasarkan tingkat pendidikan.

\begin{tabular}{clrc}
\hline No & $\begin{array}{c}\text { Tingkat } \\
\text { Pendidikan }\end{array}$ & Jumlah & $\%$ \\
\hline 1 & SD & 5 & 16,67 \\
2 & SMP & 21 & 70,00 \\
3 & SMA & 3 & 10,00 \\
4 & PT & 1 & 03,00 \\
\hline \multicolumn{2}{l}{ Jumlah } & 30 & 100,0 \\
\hline
\end{tabular}

Sumber : Analisis data primer (2017)

Tabel 1. Klasifikasi Umur Responden Petani Padi Semi Organik.

\begin{tabular}{cccc}
\hline No & Tingkat Umur (Tahun) & $\begin{array}{c}\text { Jumlah Petani } \\
\text { (Orang) }\end{array}$ & Persentase (\%) \\
\hline 1 & $30-39$ & 5 & 16,67 \\
2 & $40-49$ & 13 & 43,33 \\
3 & $50-59$ & 10 & 33,33 \\
4 & $60-69$ & 2 & 6,67 \\
\hline Sumber: Data Primer (2017) & Jumlah & 30 & 100 \\
\hline
\end{tabular}




\section{Identitas Pedagang Sampel}

\section{a). Pedagang Pengepul}

Pedagang pengumpul dalam penelitian ini dipilih secara sengaja berdasarkan informasi yang didapat dari petani contoh. Pedagang pengumpul dalam penelitian ini berjumlah 2 orang. Pedagang pengumpul yang dimaksud dalam penelitian ini adalah pabrik penyimpanan beras semi organik yang terletak di Desa Pegayut Kecamatan Pemulutan dan pedagang pengepul yang ada di Desa Pangkalan Gelebak. Pedagang pengumpul membeli beras semi organik dari petani di desa tersebut dan mengemasnya kemudian dijual ke pedagang pengecer, atau langsung dijual ke konsumen.

\section{b). Pedagang Pengecer}

Pedagang pengecer adalah pedagang yang membeli beras dari pedagang pengumpul dan kemudian menjual beras tersebut secara eceran di pasar. Pedagang pengecer dalam penelitian ini berjumlah 1 orang yang ada di pasar Jakabaring yang membeli beras dari pedagang pengumpul di Desa Pangkalan Gelebak atau dari Gudang Beras Semi Organik di Desa Pegayut Kecamatan Pemulutan.

\section{Saluran Pemasaran}

Saluran pemasaran adalah seperangkat organisasi yang saling tergantung yang terlibat dalam proses pembuatan produk dan jasa yang berguna untuk dipakai atau dikonsumsi. Saluran pemasaran ada yang berbentuk sederhana dan rumit. Hal ini tergantung dari macam komoditi, lembaga pemasaran dan struktur pasar. Berikut saluran pemasaran beras semi organik yang ada di Desa Pangkalan Gelebak Kecamatan Rambutan Kabupaten Banyuasin dapat dilihat pada Gambar 1 berikut ini:

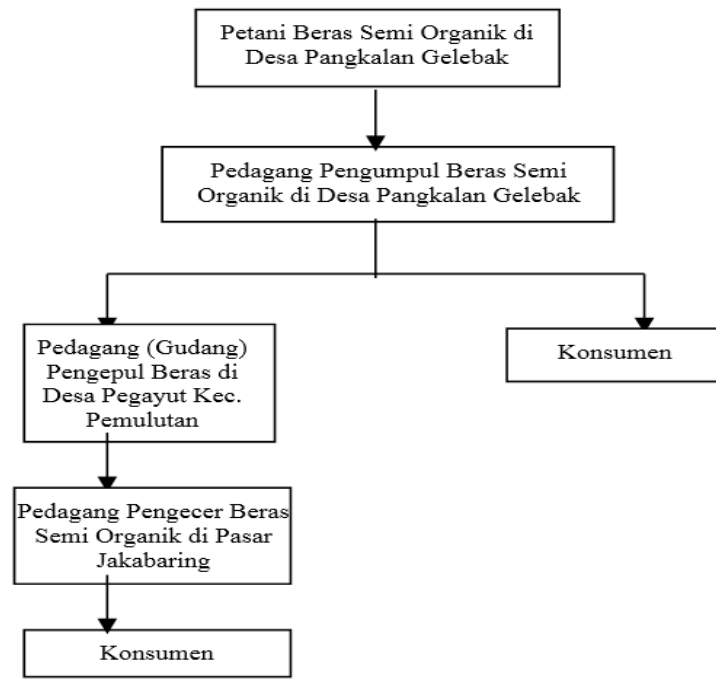

Gambar 1. Skema saluran pemasaran beras semi organik di Desa Pangkalan Gelebak Kecamatan Rambutan.

Berdasarkan Gambar 1, saluran pemasaran beras semi organik di Desa Pangkalan Gelebak terdapat dua saluran pemasaran dan melibatkan dua lembaga pemasaran yaitu pedagang pengumpul dan pedagang pengecer. Berikut penjelasan mengenai saluran pemasaran beras semi organik yang ada di Desa Pangkalan Gelebak Kecamatan Rambutan.

\subsection{Saluran Pemasaran I Beras Semi Organik}

Pada saluran pemasaran pertama di Desa Pangkalan Gelebak, petani menjual beras semi organik ke pedagang pengumpul di Desa Pangkalan Gelebak. Pedagang pengumpul yang dimaksud adalah pabrik penggilingan padi milik Bapak Rony di Desa Pangkalan Gelebak yang juga membeli beras semi organik untuk ditampung dan dijual ke gudang atau pedagang pengepul di Desa Pegayut Kecamatan Pemulutan. Petani menjual beras semi organik karena berbagai alasan yaitu karena langganan, memiliki kekerabatan dengan pedagang pengumpul, dan tetangga. Setelah itu pedagang pengumpul mengemas beras semi organik tersebut menjadi beras yang siap dijual. Kemudian pedagang pengumpul menjual berasnya ke gudang dan selanjutnya dari gudang atau pedagang pengepul besar di Desa Pegayut akan dijual ke pihak pengecer dan selanjutnya baru dijual ke konsumen. Pedagang pengecer dalam saluran pemasaran ini adalah pedagang pengecer di Pasar Jakabaring yang khusus menjual beras semi organik.

\subsection{Saluran Pemasaran II Beras Semi Organik}

Pada saluran pemasaran kedua di Desa Pangkalan Gelebak, pedagang pengumpul menjual beras semi organik hasil produksinya langsung kepada konsumen tanpa perantara lembaga pemasaran yang lainnya. Sebagian besar konsumen pada saluran pemasaran ini memilih untuk membeli beras semi organik langsung kepada pedagang pengumpul dengan berbagai alasan seperti harga yang lebih murah, langganan, tetangga, dan lain-lain.

\section{Analisis Tingkat Efisiensi Pemasaran}

Efisiensi pemasaran merupakan salah satu hal yang perlu diperhatikan dalam suatu kegiatan 
pemasaran. Pemasaran yang efisien akan tercipta apabila pihak produsen dan lembaga pemasaran serta konsumen memperoleh kepuasan dengan adanya aktifitas pemasaran yang ada. Sistem pemasaran yang tidak efisien mengakibatkan kecilnya bagian yang diterima produsen dan konsumen membayar tinggi.

Selain itu, tingkat efisiensi pemasaran juga dapat dilihat dari beberapa hal yaitu perhitungan marjin pemasaran, besarnya biaya pemasaran, besarnya keuntungan pemasaran, besarnya bagian yang diterima oleh petani (farmer's share) dan besarnya bagian yang diterima oleh lembaga pemasaran (trader's share) serta tingkat efisiensi masing-masing lembaga pemasaran yang terlibat dalam proses tataniaga. Adapun uraian dari masing-masing perhitungan tersebut dalam penelitian ini dapat dijelaskan sebagai berikut.

\subsection{Marjin Pemasaran}

Marjin pemasaran merupakan selisih antara harga jual dan harga beli dari suatu produk pada setiap lembaga pemasaran yang terlibat dalam suatu kegiatan pemasaran. Di Desa Pangkalan Gelebak terdapat dua saluran pemasaran beras. Saluran pertama melibatkan pedagang pengumpul dan pedagang pengecer. Petani menjual beras semi organik ke pedagang pengumpul desa yang merupakan pabrik atau penggilingan beras kemudian dari pedagang pengumpul di Desa Pangkalan Gelebak akan dijual ke Pedagang Pengepul (gudang) di Desa Pegayut dan selanjutnya baru dijual ke pedagang pengecer untuk dijual secara eceran. Harga beli dan harga jual serta marjin pemasaran dari setiap lembaga pemasaran pada saluran pemasaran I dapat dilihat pada Tabel 3 berikut.

Tabel 3. Harga beli, harga jual, dan marjin pemasaran beras semi organik pada saluran pemasaran I.

\begin{tabular}{|c|c|c|c|c|}
\hline No & $\begin{array}{l}\text { Lembaga } \\
\text { Pemasaran }\end{array}$ & $\begin{array}{c}\text { Harga } \\
\text { Beli } \\
(\mathrm{Rp} / \mathrm{Kg})\end{array}$ & $\begin{array}{c}\text { Harga } \\
\text { Jual } \\
(\mathrm{Rp} / \mathrm{Kg})\end{array}$ & $\begin{array}{c}\text { Margin } \\
(\mathrm{Rp} / \mathrm{Kg})\end{array}$ \\
\hline 1 & Petani & - & 8.000 & - \\
\hline 2 & $\begin{array}{l}\text { Pedagang } \\
\text { Pengumpul } \\
\text { Pedagang }\end{array}$ & 8.000 & 9.500 & 1.500 \\
\hline 3 & $\begin{array}{l}\text { Besar } \\
\text { (Gudang) }\end{array}$ & 9.500 & 10.500 & 1.000 \\
\hline 4 & $\begin{array}{l}\text { Pedagang } \\
\text { Pengecer }\end{array}$ & 10.500 & 11.500 & 1.000 \\
\hline
\end{tabular}

Sumber : Data Primer (2017)
Pada saluran pemasaran I beras semi organik dapat dilihat bahwa marjin pemasaran pedagang pengumpul lebih besar daripada marjin pemasaran pedagang pengecer. $\mathrm{Hal}$ ini dikarenakan pedagang pengumpul mengeluarkan biaya pemasaran lebih banyak daripada pedagang pengecer. Karena pedagang pengumpul merupakan pabrik penyimpanan beras semi organik yang membeli beras semi organik dari petani dan dikemas untuk dijual ke pedagang pengecer atau langsung ke konsumen. Sedangkan marjin pemasaran pedagang pengumpul di Desa Pangkalan Gelebak sebesar $\mathrm{Rp} 1.500,00$. Hal ini dikarenakan jarak antara pedagang pengumpul tingkat desa dan gudang cukup jauh, sehingga pedagang pengecer mengeluarkan biaya transportasi yang lumayan besar. Pada saluran pemasaran ini, sebagian beras semi organik di pedagang pengumpul dijual ke pedagang pengecer di Pasar Jakabaring Kota Palembang.

Pada saluran pemasaran II, hanya melibatkan satu lembaga pemasaran yaitu pedagang pengumpul di Desa Pangkalan Gelebak. Pedagang pengumpul pada saluran pemasaran II adalah pedagang pengumpul yang ada di saluran pemasaran I. Marjin pemasaran dari setiap lembaga pemasaran pada saluran pemasaran II dapat disajikan pada Tabel 4 sebagai berikut:

Tabel 4. Harga beli, harga jual, dan marjin pemasaran beras semi organik pada saluran pemasaran II.

\begin{tabular}{rlrrr}
\hline No. & $\begin{array}{l}\text { Lembaga } \\
\text { Pemasaran }\end{array}$ & $\begin{array}{c}\text { Harga } \\
\text { Beli } \\
(\mathrm{Rp} / \mathrm{Kg})\end{array}$ & $\begin{array}{c}\text { Harga } \\
\text { Jual } \\
(\mathrm{Rp} / \mathrm{Kg})\end{array}$ & $\begin{array}{c}\text { Margin } \\
\text { Pemasaran } \\
(\mathrm{Rp} / \mathrm{Kg})\end{array}$ \\
\hline 1 & Petani & - & 8.000 & - \\
2 & $\begin{array}{l}\text { Pedagang } \\
\text { Pengumpul }\end{array}$ & 8.000 & 9.000 & 1.000 \\
\hline
\end{tabular}

Sumber : Data Primer (2017)

Berdasarkan Tabel 4 dapat dilihat bahwa pada saluran pemasaran II diperoleh marjin pemasaran pedagang pengumpul sebesar $\mathrm{Rp}$ $1.000,00$ per kilogram. Marjin pemasaran pedagang pengumpul pada saluran II agak berbeda dikarenakan pada saluran kedua ini pihak pedagang pengepul di Desa Pangkalan Gelebak langsung menjual ke pihak konsumen dan biasanya konsumen akan datang sendiri ke pabrik penggilingan padi sehingga berpengaruh terhadap biaya pemasaran yang berkurang terutama untuk biaya transportasi. 


\subsection{Biaya Pemasaran}

Biaya pemasaran adalah biaya yang dikeluarkan untuk keperluan pemasaran suatu produk yang meliputi biaya transportasi, biaya tenaga kerja, dan biaya-biaya lainnya yang diperlukan dalam saluran pemasaran. Biaya pemasaran terjadi karena adanya jarak antara produsen dan konsumen. Bila jarak antara produsen dan konsumen tersebut pendek maka biaya pengangkutan bisa diperkecil. Semakin panjang jarak dari produsen atau dari pedagang ke konsumen akan semakin banyak perantara (lembaga pemasaran) yang terlibat, maka biaya pemasaran akan semakin tinggi.

Aktifitas pemasaran beras memerlukan biaya pemasaran. Kemudian biaya pemasaran tersebut dikeluarkan oleh setiap lembaga pemasaran yang terlibat. Biaya pemasaran yang ditanggung oleh setiap lembaga pemasaran dalam setiap saluran relatif sama. Pada semua saluran yang ada, petani sebagai produsen tidak mengeluarkan biaya pemasaran untuk memasarkan beras semi organik melainkan semua biaya pemasaran tersebut ditanggung oleh pedagang pengumpul karena pedagang pengumpul mengupah orang untuk mengangkut beras semi organik dari rumah petani sampai ke pabrik penyimpanan atau ke gudang milik pedagang pengumpul.

Besarnya biaya pemasaran dapat dipengaruhi oleh beberapa hal seperti jarak, skala usaha pedagang, jumlah tenaga kerja, dan kualitas dari beras semi organik. Besarnya biaya pemasaran akan mempengaruhi harga pada tingkat konsumen akhir dan farmer's share. Biaya pemasaran juga mempengaruhi penilaian efisien atau tidaknya suatu lembaga pemasaran dalam menyalurkan barangnya.

Lembaga pemasaran yang terlibat pada pemasaran beras semi organik di Desa Pangkalan Gelebak adalah pedagang pengumpul pada saluran pemasaran I dan II, serta pedagang pengecer pada saluran pemasaran I. Kemudian untuk penjelasan mengenai biaya pemasaran yang dikeluarkan oleh setiap lembaga pemasaran yang terlibat pada masing-masing saluran pemasaran beras semi organik di Desa Pangkalan Gelebak dapat dilihat sebagai berikut;

\section{a). Pedagang Pengepul pada Saluran Pemasaran I dan II}

Pedagang pengumpul yang ada pada saluran pemasaran I dan II merupakan pedagang yang sama dan memiliki jumlah biaya yang sama besarnya dikarenakan kesamaan mekanisme pemasaran yang terjadi pada pedagang pengumpul di saluran pemasaran I dan II. Dalam saluran pemasaran I dan II ini, biaya pemasaran yang dikeluarkan oleh pedagang pengumpul di Desa Pangkalan Gelebak adalah biaya tenaga kerja, biaya pengemasan, biaya pemeliharaan alat yang dikeluarkan untuk memperbaiki alat yang rusak, dan penyusutan alat mesin pengolahan beras, dan penyusutan bangunan.

Pada saluran pemasaran I, pedagang pengumpul menjual berasnya ke pedagang pengepul besar (gudang) di Desa Pegayut. Selanjutnya pedagang pengepul besar menjual beras sebagian ke pengecer. Pedagang pengecer membeli beras semi organik langsung ke pedagang pengumpul besar. Sehingga pedagang pengumpul yang ada di desa tersebut tidak mengeluarkan biaya transportasi dalam memasarkan beras semi organik. Biasanya biaya tenaga kerja yang dikeluarkan pedagang pengumpul itu terdiri dari biaya tenaga angkut beras semi organik dari rumah petani ke pabrik penyimpanan pedagang pengumpul, dari pedagang pengumpul ke pedagang pengecer, maupun ke konsumen lainnya. Namun, pada saluran pemasaran II pedagang pengumpul di Desa Pangkalan Gelebak menjual beras semi organik langsung ke konsumen. Konsumen langsung datang ke pedagang pengumpul untuk membeli berasnya sehingga pedagang pengumpul tidak mengeluarkan biaya transportasi. Besarnya biaya pemasaran yang dikeluarkan oleh pedagang pengumpul pada saluran pemasaran I dan saluran pemasaran II dapat dilihat pada Tabel. 5 berikut ini:

Tabel 5. Biaya pemasaran pada tingkat pedagang pengumpul pada saluran pemasaran

\begin{tabular}{|c|c|c|c|c|}
\hline \multirow[b]{2}{*}{ No } & \multirow{2}{*}{$\begin{array}{c}\text { Komponen } \\
\text { Biaya }\end{array}$} & \multicolumn{3}{|c|}{ Jumlah Biaya } \\
\hline & & Rp/Tahun & $\begin{array}{l}\mathrm{Rp} / \\
\mathrm{Kg}\end{array}$ & $\%$ \\
\hline 1 & Tenaga Kerja & 8.800 .000 & 40,00 & 76,26 \\
\hline 2 & Pengemasan & 2.000 .000 & 9,09 & 17,33 \\
\hline 3 & $\begin{array}{l}\text { Pemeliharaan } \\
\text { Alat }\end{array}$ & 200.000 & 0,90 & 1,73 \\
\hline 4 & $\begin{array}{l}\text { Penyusutan } \\
\text { Alat }\end{array}$ & 180.000 & 0,82 & 1,56 \\
\hline 5 & $\begin{array}{l}\text { Penyusutan } \\
\text { Bangunan }\end{array}$ & 360.000 & 1,64 & 3,12 \\
\hline & Total & 11.540 .000 & 52,45 & 100,00 \\
\hline
\end{tabular}

Sumber : Data Primer (2017) 
Berdasarkan Tabel 0.5 dapat dilihat bahwa biaya pemasaran terbesar yang dikeluarkan oleh pedagang pengumpul adalah biaya untuk tenaga kerja yaitu sebesar Rp 8.800.000,00 per tahun atau sebesar 76,26 persen dari total biaya yang dikeluarkan oleh pedagang pengumpul pada tahun 2017. Dari total biaya yang dikeluarkan adalah $\mathrm{Rp}$ 11.540.000,00 dengan volume beras sebanyak 220.000 kilogram, maka biaya per satuan kilogram beras di tingkat pedagang pengumpul di Desa Pangkalan Gelebak adalah Rp 52,45 per kilogram. Besarnya biaya pemasaran yang dikeluarkan oleh pedagang pengumpul di Desa Pangkalan Gelebak pada tiap saluran pemasaran.

\section{b). Pedagang Pengecer di Pasar Jakabaring pada Saluran Pemasaran I}

Besarnya biaya pemasaran yang dikeluarkan oleh pedagang pengecer di Pasar Jakabaring meliputi biaya biaya transportasi, biaya pengemasan, dan biaya sewa tempat. Besarnya biaya pemasaran yang dikeluarkan oleh pedagang pengecer ini dapat dilihat pada Tabel 6 berikut ini:

Tabel 6. Biaya Pemasaran pada tingkat pedagang pengecer di Pasar Jakabaring pada saluran pemasaran I.

\begin{tabular}{llrrr}
\hline \multirow{2}{*}{ No } & Komponen & \multicolumn{3}{c}{ Jumlah Biaya } \\
\cline { 4 - 5 } & Biaya & Rp/Tahun & $\mathrm{Rp} / \mathrm{Kg}$ & $\%$ \\
\hline 1 & Transportasi & 1.380 .000 & 55,20 & 20,06 \\
2 & Sewa & 5.500 .000 & 220,00 & 79,94 \\
\hline & Tempat & 6.880 .000 & 275,20 & 100,00 \\
\hline & Total & & &
\end{tabular}

Sumber : Data Primer (2017)

Berdasarkan Tabel 6 di atas, dapat dilihat bahwa komponen biaya pemasaran terbesar yang dikeluarkan oleh pedagang pengecer pada saluran pemasaran I adalah biaya untuk menyewa tempat yaitu sebesar Rp 5.500.000,- Besarnya biaya pemasaran pada tingkat pedagang pengecer di Pasar Jakabaring pada saluran pemasaran I.

\section{c). Keuntungan Pemasaran}

Keuntungan pemasaran merupakan selisih antara penerimaan dengan biaya pemasaran yang dikeluarkan. Perbedaan jumlah lembaga pemasaran akan mempengaruhi besarnya keuntungan per lembaga dan pada akhirnya mempengaruhi keuntungan total saluran pemasaran tertentu. Terdapat dua saluran pemasaran beras semi organik yang ada di Desa Pangkalan Gelebak. Saluran pemasaran I melibatkan dua lembaga pemasaran yaitu pedagang pengumpul di Desa Pangkalan
Gelebak dan pedagang pengepul besar (gudang) di Desa Pegayut serta pengecer. Besarnya keuntungan pemasaran yang diperoleh setiap lembaga pemasaran pada saluran pemasaran I dapat dilihat pada Tabel 7 berikut ini:

Tabel 7. Keuntungan pemasaran di tingkat lembaga pemasaran beras semi organik pada saluran pemasaran tingkat I

\begin{tabular}{|c|c|c|}
\hline $\begin{array}{l}\text { Lembaga } \\
\text { Pemasaran }\end{array}$ & Uraian (Per Tahun) & Nilai \\
\hline \multirow{4}{*}{$\begin{array}{c}\text { Pedagang } \\
\text { Pengumpul } \\
\text { di Desa P. } \\
\text { Gelebak }\end{array}$} & $\begin{array}{l}\text { Marjin Pemasaran } \\
(\mathrm{Rp} / \mathrm{Kg})\end{array}$ & 1.500 \\
\hline & $\begin{array}{l}\text { Biaya Pemasaran } \\
(\mathrm{Rp} / \mathrm{Kg})\end{array}$ & 52,45 \\
\hline & $\begin{array}{l}\text { Keuntungan } \\
\text { Pemasaran }(\mathrm{Rp} / \mathrm{Kg})\end{array}$ & $1.477,55$ \\
\hline & $\begin{array}{l}\text { Total Keuntungan } \\
\text { Pemasaran (Rp) }\end{array}$ & 325.061 .000 \\
\hline \multirow{4}{*}{$\begin{array}{c}\text { Pedagang } \\
\text { Pengepul } \\
\text { Besar } \\
\text { di Desa } \\
\text { Pegayut }\end{array}$} & $\begin{array}{l}\text { Marjin Pemasaran } \\
(\mathrm{Rp} / \mathrm{Kg})\end{array}$ & 1.000 \\
\hline & $\begin{array}{l}\text { Biaya Pemasaran } \\
(\mathrm{Rp} / \mathrm{Kg})\end{array}$ & 52,45 \\
\hline & $\begin{array}{l}\text { Keuntungan } \\
\text { Pemasaran }(\mathrm{Rp} / \mathrm{Kg})\end{array}$ & 947,55 \\
\hline & $\begin{array}{l}\text { Total Keuntungan } \\
\text { Pemasaran (Rp) }\end{array}$ & 208.461 .000 \\
\hline \multirow[t]{4}{*}{$\begin{array}{l}\text { Pedagang } \\
\text { Pengecer }\end{array}$} & $\begin{array}{l}\text { Marjin Pemasaran } \\
(\mathrm{Rp} / \mathrm{Kg})\end{array}$ & $1.000,00$ \\
\hline & $\begin{array}{l}\text { Biaya Pemasaran } \\
(\mathrm{Rp} / \mathrm{Kg})\end{array}$ & 275,20 \\
\hline & $\begin{array}{l}\text { Keuntungan } \\
\text { Pemasaran }(\mathrm{Rp} / \mathrm{Kg})\end{array}$ & 724,80 \\
\hline & $\begin{array}{l}\text { Total Keuntungan } \\
\text { Pemasaran (Rp) }\end{array}$ & $159.456 .000,00$ \\
\hline
\end{tabular}

Berdasarkan Tabel 7 di atas dapat dilihat bahwa besarnya keuntungan pemasaran yang diterima oleh pedagang pengumpul di Desa Pangkalan Gelebak lebih besar dibandingkan keuntungan yang diterima oleh pedagang pengepul besar dan pengecer dalam setahun. Sedangkan keuntungan pemasaran yang diterima oleh pedagang pengecer pada saluran pemasaran ini hanya sebesar Rp 724,80 per kilogram dengan total keuntungan pemasaran sebesar Rp 159.456.000,00 dalam setahun. Kemudian untuk saluran pemasaran II beras semi organik di Desa Pangkalan Gelebak hanya melibatkan satu lembaga pemasaran, yaitu pedagang pengumpul di Desa Pangkalan Gelebak yang merupakan pabrik penggilingan padi. 
Tabel 8. Keuntungan pemasaran di tingkat lembaga pemasaran beras semi organik pada saluran pemasaran tingkat II

\begin{tabular}{|c|c|c|}
\hline $\begin{array}{c}\text { Lembaga } \\
\text { Pemasaran }\end{array}$ & $\begin{array}{c}\text { Uraian (Per } \\
\text { Tahun) }\end{array}$ & Nilai \\
\hline Pedagang & Marjin & \\
\hline \multirow[t]{6}{*}{ Pengumpul } & $\begin{array}{l}\text { Pemasaran }(\mathrm{Rp} / \\
\mathrm{Kg})\end{array}$ & $1.000,00$ \\
\hline & $\begin{array}{l}\text { Biaya Pemasaran } \\
(\mathrm{Rp} / \mathrm{Kg})\end{array}$ & 52,45 \\
\hline & Keuntungan & \\
\hline & Pemasaran (Rp/ & 947,55 \\
\hline & $\begin{array}{l}\mathrm{Kg}) \\
\text { Total }\end{array}$ & \\
\hline & $\begin{array}{l}\text { Keuntungan } \\
\text { Pemasaran (Rp) }\end{array}$ & $208.461 .000,00$ \\
\hline
\end{tabular}

Berdasarkan Tabel 8 di atas dapat dilihat bahwa besarnya keuntungan pemasaran pedagang pengumpul pada saluran pemasaran II di Desa Pangkalan Gelebak sebesar Rp 947,00 per kilogram dengan total keuntungan pemasaran sebesar Rp 208.461.000 dalam setahun.

\section{d). Farmer's Share dan Trade Share}

Farmer's share atau bagian yang diterima petani merupakan persentase perbandingan harga yang ada di tingkat petani dengan harga yang ada di tingkat konsumen. Hasil bagian yang diterima oleh petani baik kecil maupun besar menunjukkan merata atau tidaknya pembagian hasil oleh pedagang pengumpul, pedagang besar, dan pedagang pengecer terhadap petani. Bagian yang diterima petani akan semkain kecil jika terlalu banyak pihak yang terlibat dalam pemasaran beras semi organik. Trader's share atau bagian yang diterima petani merupakan persentase perbandingan antara harga di tingkat pedagang dengan harga di tingkat konsumen akhir. Besarnya bagian yang diterima oleh petani dan pedagang pengumpul desa dan pedagang besar serta pedagang pengecer beras semi organik di Desa Pangkalan Gelebak yang terlibat dalam saluran pemasaran I dan saluran pemasaran II dapat dilihat pada Tabel 9. berikut ini:
Tabel 9. Bagian yang diterima petani (farmer's share) dan bagian yang diterima pedagang (trader's share) pada salurna pemasaran I dan II.

\begin{tabular}{|c|c|c|c|}
\hline \multirow[b]{2}{*}{ No. } & \multirow[b]{2}{*}{ Uraian } & \multicolumn{2}{|c|}{ Nilai (\%) } \\
\hline & & $\begin{array}{c}\text { Saluran } \\
\text { I }\end{array}$ & $\begin{array}{c}\text { Saluran } \\
\text { U }\end{array}$ \\
\hline 1 & $\begin{array}{l}\text { Farmer's Share } \\
\text { Trader's Share } \\
\text { Pedagang }\end{array}$ & 69,56 & 88,88 \\
\hline 2 & $\begin{array}{l}\text { Pengumpul di } \\
\text { Desa Pangkalan } \\
\text { Gelebak } \\
\text { Trader's Share } \\
\text { Pedagang }\end{array}$ & 82,60 & 100,00 \\
\hline 3 & $\begin{array}{l}\text { Pengumpul Besar } \\
\text { (gudang) di Desa } \\
\text { Pegayut } \\
\text { Trader's Share }\end{array}$ & 91,30 & - \\
\hline 4 & $\begin{array}{l}\text { Pedagang } \\
\text { Pengecer }\end{array}$ & 100,00 & \\
\hline
\end{tabular}

Berdasarkan Tabel 9 dapat dilihat bahwa bagian yang diterima petani pada saluran pemasaran I adalah sebesar 69,56 persen dari harga jual di tingkat pedagang pengecer ke konsumen. Kemudian bagian yang diterima oleh pedagang pengumpul di Desa Pangkalan Gelebak adalah sebesar 82,60 persen dari harga jual pedagang pengecer ke konsumen. Sedangkan bagian yang diterima oleh pedagang pengepul besar (gudang) sebesar 91,30 persen serta di tingkat pengecer adalah sebesar 100,00 persen karena pada saluran pemasaran ini pedagang pengecer menjual beras semi organik langsung ke konsumen. Pada saluran pemasaran II dapat dilihat bahwa bagian yang diterima petani adalah sebesar 88,88 persen dari harga jual pedagang pengumpul ke konsumen. Sedangkan bagian yang diterima oleh pedagang pengumpul adalah 100,00 persen karena pedagang pengumpul pada saluran ini menjual beras semi organik langsung ke konsumen.

\section{Struktur dan Perilaku Pemasaran 5.1. Struktur Pasar}

Struktur pasar adalah keadaan yang menyatukan tingkat persaingan suatu pasar, meliputi jumlah produksi dalam pasar, distribusi, deskripsi produk dan diferensiasi produk serta syarat masuk pasar. Struktur pasar menggambarkan tingkat persaingan di suatu pasar barang atau jasa tertentu. Karakteristik 
pasar yang paling penting adalah jumlah dan ukuran distribusi para penjual dan pembeli serta tingkat diferensiasi produk yang diperjualbelikan dari pasar tersebut.

Lembaga pemasaran yang terlibat dalam pemasaran beras semi organik terdiri dari tiga lembaga yaitu petani, pedagang pengumpul tingkat desa, dan lemabga pengepul besar (gudang) serta pedagang pengecer. Petanimenjual beras semi organik ke pedagang pengumpul, dari pedagang pengumpul disalurkan ke pedagang pengepul besar selanjutnya dijual ke pengecer dan ada juga yang langsung ke konsumen, kemudian pedagang pengecer menjual beras semi organiknya ke konsumen akhir. Untuk lebih jelas mengenai struktur pasar beras semi organik yang ada di Desa Pangkalan Gelebak dapat dilihat pada Tabel 10, diketahui bahwa produsen (petani), pedagang pengumpul, dan pedagang pengecer memiliki struktur pasar persaingan monopolistik. Dinyatakan sebagai pasar persaingan monopolistik karena struktur pasar beras semi organik di Desa Pangkalan Gelebak ini memiliki karakteristik yang mendukung terjadinya pasar bersaing sempurna. Mulai dari adanya kebebasan dari masing-masing lembaga pemasaran untuk keluar dan masuk pasar, adanya kebebasan dalam menentukan jumlah barang yang diperjualbelikan, produk yang bersifat standar, jumlah penjual yang sedikit dan jumlah pembeli yang sama-sama banyak, dan penetapan harga ditentukan oleh penjual dan pembeli. Kebebasan penjual dan pembeli untuk keluar masuk pasar telah menjelaskan bahwa penjual bebas menjual beras semi organik tanpa ada unsur paksaan dari penjual lainnya. Sebagian besar transaksi yang terjadi antara penjual dan pembeli karena pada umumnya para penjual telah memiliki banyak pelanggan. Sehingga beras semi organik bisa dijual tanpa adanya hambatan.

\subsection{Perilaku Pemasaran}

Perilaku pemasaran merupakan pola tingkah laku dari para pelaku-pelaku pemasaran yang menyangkut peristiwa sosial. Para pelaku pasar terdiri dari produsen, konsumen, dan lembaga pemasaran. Produsen adalah petani yang bertindak dalam memasarkan beras semi organik hingga sampai kepada konsumen. Sedangkan konsumen adalah seseorang yang melakukan pembelian beras semi organik untuk dikonsumsi. Kemudian lembaga pemasaran adalah seseorangataukelompokyang membentuk badan usaha untuk menyalurkan beras semi organik agar sampai ke tangan konsumen akhir.

Berdasarkan hasil penelitian di lapangan dapat dilihat bahwa sebagian beras semi organik

Tabel 10. Karakteristik pemasaran pada lembaga pemasaran beras semi organik di Kecamatan Rambutan.

\begin{tabular}{|c|c|c|c|c|}
\hline \multirow[b]{2}{*}{ No. } & \multirow[b]{2}{*}{ Karakteristik } & \multicolumn{3}{|c|}{ Lembaga Pemasaran } \\
\hline & & $\begin{array}{c}\text { Petani } \\
\text { (Pedagang Desa) }\end{array}$ & $\begin{array}{l}\text { Pedagang } \\
\text { Pengumpul } \\
\text { (Pabrik) }\end{array}$ & $\begin{array}{l}\text { Pedagang } \\
\text { Pengecer }\end{array}$ \\
\hline 1 & Jumlah penjual & Banyak & Sedikit & Sedikit \\
\hline 2 & Jumlah pembeli & Banyak & Banyak & Banyak \\
\hline 3 & $\begin{array}{l}\text { Kebebasan keluar masuk } \\
\text { pasar }\end{array}$ & & & \\
\hline & - Penjual & Bebas & Bebas & Bebas \\
\hline 4 & $\begin{array}{l}\text { - Pembeli } \\
\text { Kekuasaan penetapan } \\
\text { jumlah barang yang } \\
\text { diperiualbelikan }\end{array}$ & Bebas & Bebas & Bebas \\
\hline & - Penjual & Bebas & Bebas & Bebas \\
\hline 5 & $\begin{array}{l}\text { - Pembeli } \\
\text { Sifat Produk }\end{array}$ & Bebas & Bebas & Bebas \\
\hline 6 & $\begin{array}{l}\text { - Beras Semi Organik } \\
\text { Penetapan Harga }\end{array}$ & Standar & Standar & Standar \\
\hline & - Penjual & Penerima harga & Penentu harga & Penentu harga \\
\hline & - Pembeli & Kekuatan pasar & Penentu harga & Penerima harga \\
\hline 7 & Struktur Pasar & $\begin{array}{c}\text { Bersaing } \\
\text { sempurna }\end{array}$ & $\begin{array}{c}\text { Persaingan } \\
\text { Monopolistik }\end{array}$ & $\begin{array}{c}\text { Persaingan } \\
\text { Monopolistik }\end{array}$ \\
\hline
\end{tabular}


dipasarkan langsung oleh petani ke pedagang pengumpul, kemudian pedagang pengumpul ke pedagang pengecer, dan terakhir adalah pedagang pengecer ke konsumen. Harga beras semi organik yang dipasarkan di Pangkalan Gelebak ini ditentukan oleh pedagang. Pedagang pengumpul maupun pedagang pengecer ini dalam menentukan harga jual adalah berdasarkan besarnya biaya yang dibutuhkan dalam proses pemasaran oleh masing-masing lembaga pemasaran. Kemudian dari hasil wawancara di lapangan dapat diketahui bahwa konsumen beras semi organik tidak dikuasai pihak manapun. Sehingga konsumen bebas untuk membeli beras semi organik dari pihak manapun yang mereka inginkan.

\section{KESIMPULAN}

Kesimpulan yang diperoleh dari hasil penelitian yang telah dilakukan menunjukkan bahwa saluran pemasaran yang terbentuk dari kegiatan pemasaran beras semi oraganik di wilayah Desa Pangkalan Gelebak sebanyak 2 (dua) saluran, yaitu saluran 1 (petani - pengepul tingkat desa - pengepul besar - pengecer konsumen) dan saluran 2 (petani - pedagang pengepul-konsumen). Sementara untuk struktur pasar yang terjadi termasuk dalam kategori pasar persaingan sempurna pada tingkat pedangan pengepul tingkat desa dan pasar persaingan monopolistik karena konsumen, harga, produk dan transaksi tidak dikuasai pihak manapun. Tingkat efisiensi pemasaran beras semi organik pada tiap saluran pemasaran yang terbentuk di Kecamatan Rambutan dikategorikan efisien.

Melihat hasil kajian pola pemasaran beras semi organik di Desa Pangkalan Gelebak Kecamatan Rambutan mengisyaratkan bahwa perlu adanya peran pemerintah dalam hal mendorong petani lain yang belum menerapkan pertanian secara berkelanjutan dengan cara memberikan perhatian khusus dengan pemberian stimulan bagi petani yang berhasil menerapkan pertanian organik di di suatu wilayah. Perlunya kesadaran petani padi semi organik dalam menentukan saluran pemasaran yang dipilih agar mendapatkan laba yang lebih tinggi. Dibutuhkan suatu lembaga yang berperan dalam menjaga dan menjamin keunggulan beras semi organik dibandingkan dengan beras biasa. Untuk memperluas pemasaran perlu dilakukan upaya pengembangan pemasaran beras organik melalui retail-retail tertentu seperti apotik, swalayan dan lainnya.

\section{DAFTAR PUSTAKA}

Andoko, Agus, 2005, Budidaya Padi Secara Organik, Jakarta: Penebar Swadaya.

Arbi, M. 2016. Kajian Sebaran Produksi dan Perdagangan serta Karakteristik Konsumen Sayuran Hidroponik di Kota Palembang. Madura: Jurnal Agroekonomika. Vol. 5,No. 1:54-63.

Assuari, M. 2002. Manajemen Pemasaran Dasar, Konsep, dan Strategi. Raja Grafinso Persada. Jakarta.

Badan Pusat Statistik. 2012. Kecamatan Rambutan dalam Angka 2012.BPS, Kecamatan Rambutan Kabupaten Banyuasin.

Limbong, Wilson H dan Panggabean Sitorus. 1987. Pengantar Tataniaga Pertanian. Jurusan Ilmu-ilmu Sosial Ekonomi Pertanian. Fakultas Pertanian. Institut Pertanian Bogor.

Nasoetion, A. 2011. Pengantar Ilmu-Ilmu Pertanian. PT. Pustaka Litera Antar Nusa. Jakarta.

Nurmalina, R. 2007. Model Ketersediaan Beras yang Berkelanjutan untuk Mendukung Ketahanan Pangan Nasional. Disertasi. Program Studi Ilmu Pengelolaan Sumberdaya Alam dan Lingkungan Sekolah Pascasarjana, Institut Pertanian Bogor. Bogor.

Purnamaningsih, R. 2006. Induksi Kalus dan Optimasi Regenerasi Empat Varietas Padi Melalui Kultur In Vitro. Jakarta. Jurnal Agrobiogen. Vol. 2, No. 2:74-80.

Samuelson, Paul A. Dan Nordhaus William D. 1996. Makro Ekonomi. Edisi ke- 17. Cetakan ketiga. Jakarta: Erlangga.

Sastraatmadja, E. 1987. Ekonomi Pertanian Indonesia. Angkasa. Bandung.

Shim, K. J. Dan J. G. Siegel. 1992. Modern Cost Management and Analysis. Barron's Business Library. New York. 
Sjarkowi, F. Dan M. Sufri. 2002. Manajemen Agribisnis. CV. Baldad Grafiti Press. Palembang.

Soekartawi. 1996. Prinsip Dasar Manajemen Pemasaran Hasil-Hasil Pertanian Teori dan Aplikasinya. PT. Raja Grafindo. Jakarta.

Sukristiyonubowo, R., H. Wiwik, A. Sofyan, H.P Benito, and S.D Neve. 2011. Change from Conventional to Organic Rice Farming System: Biophysical and Socioeconomic Reasons. International Research. J. Agric. Sci. Soil Sci. 1(5): 172-182.

Syohfitra, M. 2007. Analisis Pemasaran Duku dari Desa Kecamatan Rasuan Kecamatan Madang Suku Kabupaten Ogan Komering Ulu Timur ke Jakarta. Skripsi Fakultas Pertanian Universitas Sriwijaya. Indralaya.

Utomo, M. dan Nazaruddin. 2003. Bertanam Padi Sawah Tanpa Olah Tanah. Penebar Swadaya. Jakarta 